\title{
LEGAL ASPECTS OF PROTECTION OF CHILDREN AND WOMEN VICTIMS OF CRIME IN INDONESIA
}

\author{
Yusrizal, Budi Bahreisy, Ferdy Saputra \\ Faculty of Law, Malikussaleh University \\ *yusrizal@unimal.ac.id
}

\begin{abstract}
The protection of victims of crime in the Indonesian legal system has not received serious attention. This can be seen from the reality of enforcement is still at least the fulfillment of the rights of victims of crime. The imbalance of protection of victims of crime with perpetrators of crimes is basically one of the denials of the principle that every citizen has a common position in law and justice. The purpose of this writing is to find out the still unfulfilled rights of victims of crime, especially the rights of children and women. Research method used is normative juridical approach is an approach that is done based on the main legal material by studying theories, concepts, legal principles and laws and regulations related to this writing. Looking at the position of the victim there is actually no detailed provision on the form of victim protection so as to cause an imbalance in the legal gap between the victim and the perpetrator of the crime that will ultimately lead to injustice. Therefore, the government and legislature need to reformulate and draft legislation that specifically regulates the protection of victims of crime, in which will be regulated in terms of comprehensive protection of victims of crime, such as physical, financial, psychic, and medical protection.
\end{abstract}

\section{Keywords: Legal Protection. Victims, Children and Women}

\begin{tabular}{ll} 
Journal History & \\
Received & $:$ February 16, 2021; \\
Reviewed & $:$ March 27, 2021; \\
Accepted & $:$ April 07, 2021; \\
Published $\quad:$ April 14, 2021. \\
\hline Copyright @2020 NLR. All right reserved. \\
\hline
\end{tabular}

\section{INTRODUCTION}

Discourses on human rights and legal protection are actually more focused on the interests of the state, the relationship between the state and citizens, the relationship between human beings and the relationship of one country with another. If that is the case, then one of the aspects that can be used as a foothold is the interests and perspectives of ideologicalphilosophical, religious, political economics and other strategic aspects related to the fundamental interests of a nation. 
Human rights in Indonesia originate from and lead to Pancasila. Which means that human rights have a strong guarantee from the nation's philosophy, namely Pancasila. Leading to Pancasila, it means that the implementation of human rights must pay attention to the lines that have been determined in the provisions of the Pancasila philosophy. For the Indonesian people, exercising human rights does not mean exercising freely, but must pay attention to the provisions contained in the Indonesian people's view of life, namely Pancasila. This is due to the fact that basically there are no rights that can be exercised in multiple ways without considering the rights of others. Each right will be limited by the rights of others. If in exercising our rights, we do not pay attention to the rights of others, then what will happen is a conflict of rights or interests in the life of the community, nation and state. $^{1}$

Hart's thoughts lead to laws made based on the existence of an authorized authority to regulate people's lives. Legal authority lies because of the commands and sanctions that have causality. ${ }^{2}$

When the discussion has touched on the dimension of human rights with fellow human beings and the axis of interaction between the state and citizens, then "child and woman" must also be in it, which must

1 Eka N.A.M Sihombing, Pemberlakuan "Parliamentary Threshold" dan Kaitannya dengan Hak Asasi Manusia, Jurnal Konstitusi, Vol. 1, No. 1, Juni (2009), p. 28.

2 Cynthia Hadita, Registrasi Data Pribadi Melalui Kartu Prabayar Dalam Perspektif Hak Asasi Manusia (Provision of Personal Information in Prepaid SIM Card Registration from Human Rights Perspective), Jurnal HAM, Vol. 9, No. 2, December (2018). be cared for and respected its existence in private and public measure. Children and women become part of the perpetrators of the history of human civilization or citizens of the nation that can not be denied by anyone and at any time in providing legal protection, especially if they become victims of crime. ${ }^{3}$

The principle of equlity before the law needs to get serious attention from law enforcement officials, so that the principle of balance to the treatment in the fulfillment of justice can really be felt by the community. It is not the other way around that the rights of the victim should be obtained, even in certain cases the victim suffers more. Such as rape cases, cases of sexual abuse and domestic violence. The protection of the law actually provides a sense of security and dignified law enforcement concerns.

The State Ministry in Eka NAM Sihombing (2018) stated that justice is a basic human right that should be respected and guaranteed to be fulfilled. Access to justice in essence focuses on two objectives of the existence of a legal system, namely the legal system should be able to produce provisions and decisions that are fair to all people, both individually and in groups. ${ }^{4}$

The conditions of law enforcement practices for victims are even discriminated

3 Abdul Wahid dan Muhammad Irfan, Perlindungan Terhadap Korban Kekerasan Seksual (Advokasi atas Hak Asasi Perempuan), (Bandung: PT. Refika Aditama, 2001), p. xiv.

4 Eka N.A.M Sihombing, Mendorong Pembentukan Peraturan Daerah tentang Bantuan Hukum di Provinsi Sumatera Utara (Encourage of Establishing Regional Regulation Concerning Legal Aid at Province of North Sumatera), Jurnal Rechtvinding, Vol. 7, No. 3, December (2018). 
against in the acquisition of protections. Victims are often used as witnesses to uncover a criminal event, regardless of how appropriate the victim is treated. The victim of a crime not only suffers materially, physically but also psychic losses that result in the disruption of a person's soul, even in acute anomie conditions resulting in suicide. The form of protection of victims of crime in the legislation is still partial, resulting in the protection of the law against weak victims.

So far there is a presumption that legal protection has been given by the state if the perpetrator of the crime has been severely punished. Of course, this assumption is not true because the assumption of this thought is put forward, so it only pursues legal certainty, while the benefits of the law are not felt directly by someone who is the victim of a crime.

In fact, legal protection is a form of realization of human rights (human rights) that should be given to restore to its original condition. Even the state is obliged to compensate each victim of the crime. The question now is has the state compensated victims of crime? Ironic in the midst of fair law enforcement there are still many victims who have not earned their rights.

Another argument that positions the victim as a discriminated person is that when going to a hearing in court, the victim must spend money, effort and time to give testimony. So this condition really makes the victim worse.

Compare with the perpetrators of crimes that obtain adequate legal protection, from the time of arrest to the trial is still given legal assistance and treated as an innocent person before there is a court decision of permanent legal force and various other legal protections listed in the Criminal Procedure Law (KUHAP).

In Article 5 of Law No. 13 of 2006 concerning the Protection of witnesses and victims, Witnesses and Victims in the law are entitled to the following rights: Obtain protection for their personal, family, and property security, and be free from threats relating to testimony that will, is, or has been given; Participate in the process of selecting and determining forms of security protection and support; Provide information without pressure; Got a translator; Free from entangling questions; Get information about case progress; Get information about court rulings; Knowing in the event that a convict is released; Get a new identity; Getting a new place to stay; Obtain reimbursement of transportation costs according to the needs; Getting legal advice; and/or Obtain temporary living expenses assistance until the protection deadline expires; and In the event of victims of gross human rights violations, it is also entitled to medical assistance and psycho-social rehabilitation assistance.

Seeing the rights of women and children who are victims, victims as justice seekers get the justice they deserve and the state must fulfill that embodiment as a form of state responsibility, because the law guarantees it. But problems arise when the rules are applied. Until now in Indonesia has not had an official agency to deal with the provision of compensation and restitution for victims of crime. Compensation for victims is still charged to LPSK (Institute 
for The Protection of Witnesses and Victims) who still can not do much.

In contrast to the United States which has an agency that specializes in providing compensation for victims of crime. The Crime Victim's Compensation Board, the agency was formed to handle the provision of medical reimbursement assistance, funerals, lost income, and so on.

With the institution The Crime Victim's Compensation Board is certainly very useful to help victims of crime who suffer financial losses, especially if the perpetrator of the crime is unable to pay compensation to the victim of the crime as a result of suffering the victim due to a criminal act committed by the perpetrator. This institution provides assistance to victims of crime in an easy and fast way as a form of state concern to its citizens. Of course with Indonesia, in many cases victims are reluctant to deal with the law let alone ask for compensation, because later the results obtained are not balanced with the help provided.

Based on the above background, it is not wrong if we assess the position of victims of crime as if they are in a state of alienation without any serious attention from the government. Similarly, for victims who experience psychological conditions that are disturbed by a criminal act, the state's attention to victims of crime seems to be under-responded to. This condition is different if the victims of crime are high social strata, then in droves lawyers come to defend, as well as health services both physical and psychological that are prioritized by the hospital.
The benefit of this writing is to provide an understanding of how victims' protection, especially children and women, should receive serious attention from the government. The next benefit is to be the basis of law enforcement in conducting the fulfillment of justice for victims.

\section{Law Enforcement Theory}

The current reality, often separated between the problemof law enforcement (law enforcement ) and the problem of law reform / development(law reformand development). In fact, criminal law enforcement is part (subsystem) of the entire system / policy of national law enforcement which is basically also part of the system / policy of national development, it is said that because in essence criminal law policy (penal policy), both in the sense of enforcement in abstracto and in concreto is part of the overall policy of the national law enforcement system and is part of efforts to support national development. ${ }^{5}$

Although positive criminal law in Indonesia today is derived from Wetboek van Strafrecht (WvS) or the Dutch Penal Code, in law enforcement should be different from criminal law enforcement as in the Dutch era, in other words, positive criminal law enforcement should be in the context of Indonesia and even in the context of national development and national law development. This is what Indonesian law enforcement can say. One of the conclusions of the National Law Convention (March 2008) states: "Lawenforcement and public

5 Barda Nawawi Arief, Kapita Selekta Criminal Law, (Bandung: Citra Aditya Bakti, 2010), p. 316-317. 
attitudes towards the law should not ignore the circumstances and dimensions of the time when the law was enacted. "Sudarto asserts, that the criminal law of a nation is an indication of the civilization of that nation. So the enforcement of criminal law should not be based solely on formal legality but should look at the laws that live in society. ${ }^{7}$

Mohammad Hatta explained that the law is the commander and the lifeblood in all aspects of state and society life. Law as a system has a strategic role in law enforcement and is dominant in creating a just and prosperous society. ${ }^{8}$

While H.L.A. Hart in Ahmad Mujahideen also sees the law as a system that contains a set of rules, where one rule with another regulation is related in one hierarchy and has a complex structure. These hierarchies and structures play a huge role in law enforcement in democracies. ${ }^{9}$

Indonesia as a democratic country, and democracy has goals that are considered the best and logical in order to improve the welfare of society, in most countries that practice it. In the general rules of democracy the fullness of personal rights gets a good place of guarantee and protection. ${ }^{10}$

${ }^{6}$ Ibid, p. 318

7 Kumpulan Pidato-Pidato Pengukuhan, Beberapa Guru Besar Berbicara Tentang Hukum dan Pendidikan Hukum, Bandung: Alumni, 1981, p. 44.

${ }^{8}$ Moh. Hatta, Beberapa Masalah Penegakan Hukum Pidana Umum dan Pidana Khusus, (Yogyakarta: Liberty Yogyakarta, 2009), p. 1.

9 Ahmad Mujahidin, Peradilan Satu Atap di Indonesia, (Bandung: Refika Aditama, 2007), p. 48.

10 Faisal Akbar Nasution, Pemerintah Daerah dan Sumber-Sumber Pendapatan Asli Daerah, (Jakarta: Sofmedia, 2009), p. 32.
David Beetham in Faisal Akbar Nasution asserted that democracy consists of a variety of individual rights, rights of speech, rights of association, rights of protection and others, but the central point is the process of joint decision-making, which can provide preconditions and limitations for individual behavior and choices. Democratic politics, like any other political thing, asserts that we are actually social beings who live freely, and therefore require general rules and policies that meet a sense of justice.

The guarantee of protection from the government to the community must apply widely, Law enforcement essentially contains the supremacy of substantial value, namely justice. The value of justice coveted is a value that is in accordance with Pancasila as the philosophy of the Indonesian nation is a value that can maintain and maintain balance, harmony and harmony between the interests of individuals on the one hand, and the interests of other communities on the other hand. The value of justice is the most important value of every legislation, in other words, the rule of law is not only a valid rule (which has validity only) ${ }^{11}$, but also a fair rule (musthave value). ${ }^{12}$

Law enforcement always involves humans in it and also involves human behavior. The law cannot be established by itself, meaning that the law is not able to

${ }^{11}$ Dikdik M. Arief Mansyur dan Elisatris Gultom, Urgensi Perlindungan Korban Kejahatan antara Norma dan Realita, (Jakarta: RajaGrafindo Persada, 2007), p 10.

12 Romli Atmasasmita, Sistem Peradilan Pidana Kontemporer, (Jakarta: Kencana, 2010), p. 67-68. 
realize its own promises and wills listed in the (rules) of the law. Such promises and wills, for example to grant rights to a person, impose criminal charges against a person who meets certain requirements and so on. ${ }^{13}$

The occurrence of disasters in legal life in Indonesia lately, such as the judiciary against judges and the abuse of power in the law by law enforcement officials and frictions arising in the community as a result of the implementation of law enforcement, does not seem to be returned to the mentality of law enforcement executives, as is commonly stated by the public, but there is also the possibility of due to the value (justice) contained in the prevailing laws and regulations today is far from adequate, even contrary to the opinions and sense of justice of our society. ${ }^{14}$

\section{Theory of Justice}

Law enforcement in Indonesia must comply with the sense of community justice while paying attention to legal certainty in each individual citizen which is an expression of democratic values in a democratic country. The connection between democratic supporting values and elements of the state of law, it can be said that law enforcement is fair and benefits and protects the rights of democratic citizens. ${ }^{15}$ Jhon Rawls stated the purpose of the law to be fair when in its application in accordance with the soul of the positive law. So the purpose of the law is justice. Justice is fulfilled when the institutions of a society

13 Satjipto Rahardjo, Penegakan Hukum Suatu Tinjauan Sosiologis, Op. Cit, p. 7.

${ }^{14}$ Ibid, p. 69

15 Arbi Sanit, Perwakilan Politik di Indonesia, Jakarta: Rajawali, 1985, p. 25. are governed/used to achieve balance and happiness with moral and justice considerations. ${ }^{16}$

Broadly speaking, the demands of justice raised by Rawls provide a great opportunity for each individual to express themselves in order to realize the situation full of justice. By rewarding each individual, the rights that belong to each individual gain legitimacy to be respected. Rawls determines the principle of justice through a kind of treaty process among members of the community by heeding among others human cooperation, a sense of justice, rational choices, and so-called primary goods (the main things that a person wants to obtain). ${ }^{17}$

The implementation of the law should pave the way for the creation of social justice and regulate the social and economic differences of citizens so that the purpose of the application of the law benefits those less fortunate, this is as a consequence of the state of law.

\section{METHOD}

Research method used is normative juridical is an approach that is done based on the main legal material by studying the theories, concepts, legal principles and laws and regulations related to this writing. contains the kinds or properties of research

This research is descriptively analytical, is a method used to describe an ongoing condition or condition whose

${ }^{16}$ R. Abdussalam, Prospek Hukum Pidana Indonesia Dalam Mewujudkan Rasa Keadilan Masyarakat, (Jakarta: Restu Agung, 2006), p 16.

17 Rena Yulia, Viktimologi (Perlindungan Terhadap Korban Kejahatan), (Yogyakarta: Graha Ilmu, 2010), p. 134. 
purpose is to provide data on the object of research so as to be able to explore things that are ideal, then analyzed based on the theory of law or applicable laws and regulations. With this method of approach, the facts will be examined, then analyze and evaluate the problems contained in the facts or describe some issues related to victim protection. $^{18}$

The source of legal materials in this study is taken from literature studies consisting of primary legal materials, secondary legal materials and non-legal materials.

The technique of collecting legal materials to obtain data in this study was conducted through library research. This research is intended to obtain secondary data by studying literature, laws and regulations, theories, opinions of scholars related to the title of this study.

The research data obtained in this study will be compiled siatematically and dianalis. In normative juridical research conducted descriptive qualitative analysis, namely giving exposure and explaining in detail and in depth (verstehen) to uncover what is behind the real events with the intention of finding the values contained in it based on the provisions of the law.

\section{DISCUSSION}

\section{Proper Victim Protection Towards Responsive Law}

Basically the victim has a central position in the criminal justice system especially when the victim (victim witness) gives information before the trial in order to

${ }^{18}$ Zainuddin Ali, Metode Penelitian Hukum, (Jakarta: Sinar Grafika, 2009), p. 223. uncover the material truth. With the benchmarks outlined, the problem of victims of crime in the criminal justice system has changed the orientation of not only the scholars of criminal law, but also from the discipline of viktimology, as a discipline that takes the study of the field of victims in a broad sense that originally concentrated on the study of actions (victimology of art) and then diverted its orientation into a movement (victimology of action) that supports the movement to care for victims ofcrime. Therefore, the first thing is purely scientific performance, and the second thing as a social movement or political pressure for the government to pay attention to the interests of victims of crime, let alone the victims are children and women who fall into the category of vulnerable groups. ${ }^{19}$

On the basis of these reasons and the awareness and honest recognition that the practice of criminal law and the criminal justice system has now forgotten the interests of victims of crime is a good start of concern for the interests of victims. Problem victims of complex crimes, asserted the problem as an internal problem in the criminal law and the criminal justice system itself. Therefore, solving the problem of victims must go through a framework of criminal law (law enforcement) that is fair. The law governs society appropriately and usefully by determining what is required, what is permissible and/or vice versa. ${ }^{2021}$

19 Matti Joutsen, The Role of The Victim of Crime in European Criminal Justice System, (Helsinki: Heuni, 1987), p. 151.

20 Parman Soeparman, Pengaturan Hak Mengajukan Upaya Hukum Peninjauan Kembali Dalam Perkara Pidana Bagi Korban Kejahatan, (Bandung: PT. Refika Aditama, 2007), p. 112. 
The problem of children and women who are victims of crime has not been noticed and service to victims of crime is a sign of not yet or lack of justice and development of community welfare. Of course, related to this problem there needs to be special attention and adequate treatment so that various forms of violence, irregularities in the world of education and various other crimes that potentially children and women can be addressed integrally.

It must be acknowledged that there is no detailed provision on the form of victim protection that causes an imbalance in the legal gap between the victim and the perpetrator of the crime that will ultimately lead to injustice. With the lack of protection of the victim can cause the victim to be passive and tend to be non-cooperative with the officer, there is even a relationship between the lack of protection and the reluctance of the victim to report to the authorities, especially after the victim reports the role and position shifts in such a way that the paradilan feels the only party that can represent all the interests of the victim. ${ }^{22}$

Another phenomenon also arises when victim protection is enforced, namely the number of victims who are fully aware that they have been victims of crime but are reluctant to report to the police. There are various reasons that the victim stated, from these reasons there are two very important reasons: First, the victim has thethought that

21 Sudarto, Kapita Selekta Hukum Pidana, (Bandung: Alumni, 1986), Cetakan Kedua, p. 111.

22 Rena Yulia, Viktimologi (Perlindungan Hukum Terhadap Korban Kejahatan), Yogyakarta: Graha Ilmu, 2010, p. 58. the police will not be able, empowered or pay attention to do something about the report. Second, the victim feels that the crime he experienced is a personal matter between himself and the perpetrator of the crime. This reasoning often arises in crimes of decency, where the victim feels tainted if the act is reported. ${ }^{23}$

Protection of victims of crimes that become victims of children and women often also have difficulty in disclosing the truth of the case, because many victims prefer to choose the path of extra judicial action. Why is that? This action is done as an effort to avoid preaching, fear, shame especially for every violent crime that occurs in the family, some cases of sexual abuse or rape). ${ }^{24}$ That's accommmodate by Law Number 23 Year 2003 Concerning Child Protection, Law Number 23 of 2004 concerning Elimination of Domestic Violence, Law Number 13_Tahun 2006 concerning Victim Witness Protection, Law Number 16 Year 2011 Concerning Legal Aid Law Number 11 of 2012 concerning the Criminal Justice System for Children, Law Number 35 of 2014 concerning Amendments to Law Number 23 of 2002 concerning Child Protection, Government Regulation Number 65 of 2015 concerning Guidelines for the Implementation of Diversion and Handling of Children Not Aged 12 (Twelve) Years Old, Regulation of the Minister of Women Empowerment and Child Protection of the Republic of Indonesia Number 1 of 2010 concerning Minimum Service Standards for Integrated

\footnotetext{
${ }^{23}$ Made Darma Vedic, Kriminologi, Jakarta: PT. RajaGrafindo Persada, 1996, p. 96

${ }^{24}$ Ibid, p. 97
} 
Services for Women and Children Victims of Violence.

If it refers to such behavior, then in fact society has become the cause of the spreadof the dark number of crime (the dark number of crime ), of course this attitude is not good if the victim wants justice in everyproblem.

On the other hand, it is also worth noting that law enforcement always involves humans in it and also involves human behavior. The law cannot be established by itself, meaning that the law is not able to realize its own promises and wills listed in the (rules) of the law. Such promises and wills, for example to grant rights to a person, impose criminal charges against a person who meets certain requirements and so on. ${ }^{25}$

The occurrence of disasters in legal life in Indonesia lately, such as the judiciary against judges and the abuse of power in the law by law enforcement officials and frictions arising in the community as a result of the implementation of law enforcement, does not seem to be returned to the mentality of law enforcement executives, as is commonly stated by the public, but there is also the possibility of due to the value (justice) contained in the prevailing laws and regulations today is far from adequate, even contrary to the opinions and sense of justice of our society. ${ }^{26}$

Looking at the process of law enforcement against children and women who are victims of crime, it is necessary to travel in search of a responsive legal model

25 Satjipto Rahardjo, Penegakan Hukum Suatu Tinjauan Sosiologis, (Yogyakarta: Genta Publishing, 2009), p. 7.

${ }^{26}$ Ibid, p. 69. that has become an ongoing modern legal theory activity. As Jerome Frank puts it, the main purpose of legal realism is to make the law "responsive to social needs". To achieve this goal, they encouraged the expansion of "legally interconnected areas", in such a way that legal reasoning could include knowledge in a social context and have an influence on the official actions of legal officials. As with legal realism, ${ }^{27}$ sociological jurisprudensce (a legal science that uses a sociological approach) is also intended to provide the ability for legal institutions "to more thoroughly and intelligently consider the social facts on which the law is processed and applied. ${ }^{28}$

Kariangan in Hadita (2020) Associated with the use of moral responsibility in the office, Roscoe Pound pointed out that in a society which people may assume that people who are on around him are people who civilized, as a result, in the event of an act that deviates would hold accountablethe parties that did such acts, as a result, in the view of Roscoe Pound there are four things that become the basis forapplying the moral responsibility, namely: ${ }^{29}$

27 Philippe Nonet dan Philip Selznick, Law and Society in Transition: Toward Responsive Law, (New York: Harper \& Row Publisher, 1978), p. 73, Lihat juga Jerome Frank, Mr. Justice Holmes and Non-Euclicdian Legal Thingking, Cornel Law Quarterly, 1932, p. 568.

28 Roscoe Pound, Jurisprudence, St. Paul, Minn: West Publishing, 1959, hlm, 350, sebagaimana dikutip oleh Philippe Nonet dan Philip Selznick, Law and Society in Transition: Toward Responsive Law, (New York: Harper \& Row Publisher, 1978), p. 74.

29 Cynthia Hadita, Regional Autonomy Political Politics Of Regional Liability Reports To Regional Representatives In The Implementation Of Local Government, Nomoi 
1. That other people will have the hope of a good and reasonable that created the app ointment or conduct of the person's official;

2. That officials will keep its promise is based on the hope that is attached to it by a sense of morality on the citizens;

3. That they will act diligently and can be trusted in the interaction of position and work;

4. That they will refurbish anything that has acceptan ce of error or circumstances which do not unexpectedly been acceptance of erroneous or circumstances that are not presumed - would have thought, so they accept anything that sho uld not be worthy and not will be received in ordinary circumstances.

Roscoe Pound's theory of social interests is a more explicit attempt to develop a responsive legal model. In this perspective, good law should offer something more than just procedural fairness. Good laws must be competent and also fair. Such a law should be able to recognize the wishes of the public and have a commitment to achieving substantive justice.

In the future, hopefully the legal protection of victims of crime gets serious attention from state organizers and obtains susbtantif justice for victims. The role of the House of Representatives should be able to accommodate the interests of victims in the form of regulations and institutions needed by victims both for the center and the

Law Review, Volume 1, Issue 1, May 2020, p. 94. region, so that access to protection for victims is more affordable and fast. The role of fair law enforcement needs to be improved not just by image.

\section{Implementation of Forms of Protection of Victims of Crime}

Law No. 13 of 2006 on The Protection of Witnesses and Victims provides understanding of victims in a broad sense, namely a person who is suffering, not only physically or mentally or economically but can also be a combination of the three. This can be seen in Article 1 number 1 of Law No. 13 of 2006, which states the victim is a person who suffers physical, mental, and/or economic losses resulting from a criminal offence.

According to the Penal Code, the provisions governing the protection of victims of crime through reimbursement can be seen in Article 14c of the Penal Code which basically states: in the event that the judge drops a conditional criminal, then the judge can set special conditions for the convicted to indemnify either all or partly arising as a result of the crime committed.

Criminal Law materially regulates also about efforts to protect victims of crime through the provision of material compensation. According to Article $14 \mathrm{c}$ of the Criminal Code, judges can set special conditions for convicted

indemnify all or part of it as a result of its crimes. According to Barda Nawawi Arief, this provision does not escape from various obstacles in its implementation, namely: ${ }^{30}$

30 Barda Nawawi Arief, Perlindungan Korban Kejahatan dalam Proses Peradilan Pidana, 
1. The determination of compensation cannot be given by the judge as a standalone sanction in addition to the principal criminal, so only as a "special condition" for the implementation or execution of the principal criminal imposed on the convicted;

2. The determination of special conditions in the form of indemnification can only be given if the judge sentences a maximum of one year or criminal confinement;

3. Special conditions in the form of compensation is also according to the Criminal Code is only factional, not imperative.

Furthermore, in the Criminal Procedure Law (KUHAP), there are several rights that can be used by victims of crime in a criminal justice process, namely: ${ }^{31}$

a. the right to exercise control over investigators and public prosecutors, i.e. the right to object to the act of termination of investigation and/or prosecution in its capacity as an interested third party (Article 77 jo 80 KUHAP). This is important to be given in order to avoid efforts from certain parties with various motives, which intend to stop the examination process;

b. the right of the victim in relation to his position as a witness, namely the right to

artikel dalam Jurnal Hukum Pidana dan Kriminologi, Vol. 1, 1998, p. 17.

31 Dikdik M. Arief Mansyur dan Elisatris Gultom, Urgensi Pelrindungan Korban Kejahatan: Antara Norma dan Realita, Jakarta: PT. RajaGrafindo Persada, 2007, p 95-96 lihat juga Theo, Upaya Perlindungan Korban Kejahatan Melalui Lembaga Restitusi dan Kompensasi, dalam Teropong (Media Hukum dan Keadilan) Vol. II, No. 9, Juni 2003, p. 31-32. resign as a witness (Article 168 KUHAP) Testimony (witness) of the victim is very important to be obtained in order to achieve a material truth. Therefore, to prevent the victim from resigning as a witness, a proactive attitude from law enforcement officials is required to provide security guarantees for the victim and his family at the time of filing as a witness;

c. the right to claim damages for a crime/crime that befalls the victim through the merger of civil cases with criminal cases (Article 98 to Article 101). This right is granted to make it easier for victims to claim damages to the suspect/defendant. A merger request for damages can only be filed no later than before the public prosecutor submits a criminal claim, or if the public prosecutor is not present then the request is filed no later than before the judge drops the verdict. A merger of indemnity claims may be filed if the aggrieved party filed a merger of damages against the accused in the case alleged to him. The merger of indemnity claims is carried out under the law of civil proceedings and must be filed at the appeal level;

d. the right for the victim's family to allow or not allow the police to perform an autopsy (Article 134-136 kuhap). Allowing or not allowing the police to perform autopsies is also a form of protection for victims of crime, given that this autopsy issue for some circles is very closely related to religious issues, customs, and other aspects of decency. 
In relation to the protection of victims of crime other things that deserve serious attention in practice, if the perpetrator of the crime is still alive and can be tried, then the victim can still expect in the form of receipt of compensation from the perpetrator (if in warning of the verdict, the judge ordered the perpetrator to pay compensation to the victim or his family). However, the question is how can protection against victims of crime be provided if the perpetrator of the crime for various reasons has died, who will bear the losses suffered by the victim and his family?. To answer the above question, there are several forms of legal protection for victims that can be given:

\section{Compensation and Restitution}

The explanation of Article 35 of Law No. 26 of 2000 concerning Human Rights Court provides the sense of compensation that is compensation provided by the state, because the perpetrator is not able to provide full compensation that is his responsibility, while the restitution is: Compensation given to the victim or his family by the perpetrator or a third party. Restitution can be:
a. Return of property;
b. Indemnification payments for loss or suffering; Or

c. Reimbursement for a particular action.

The idea of providing compensation or compensation to victims of crime by the state, has been tried in several countries. As a consideration to develop this idea in Indonesia. It's a good idea to review the comparison materials in New Zealand and the UK as follows: ${ }^{32}$

\section{New Zealand}

Compensation in New Zealand is based on the Criminal Injuries Compesation Act of 1963 which came into force on 1 January 1964. The philosophy behind this law is based more on the obligations/responsibilities of the people to those who suffer bad luck than the accountability of the state for the failure to commit crimes. Compensation to victims is considered by a special body called the "CrimeCompesation Tribunal"which also acts as a Commission of Inquiry. The body consists of 3 (three) members who are referred for a period of 5 years. The chairman must be a jurist and from the Supreme Court who has at least 7 years of experience.

The Tribunal is authorized to compensate persons who are injured or killed in cases such as: rape, sexual intercourse/fornication of girls under 12 years of age, assault in violation of decency/indecent acts, intentional/accidental murder (completed or unfinished), intentional mistreatment/injury, serious assault, assault on children, firing of firearms or committing dangerous acts, intentional poisoning, abduction of women/girls and abduction of children.

Compensation that can be given for costs / costs incurred, financial losses, pain and suffering of victims. It should be

32 Barda Nawawi Arief, Beberapa Aspek Kebijakan Penegakan Hukum dan Pengembangan Hukum Pidana, (Bandung: PT. Citra Aditya Bakti, 1998), p. 64. 
remembered that compensation is limited to loss / damage to the person / victim itself (Personal Injuries) not to loss / damage to wealth. The amount of compensation given can be in the form of a lump sum or in the form of periodic payments.

\section{English}

Compensation in the UK is held not because the state has a legal responsibility to pay, but is based on the view that it is part of a social obligation or social policy and as an extension of the welfare system. Compensation in the UK is rather unique, because payments are only made only for cases that are appropriate / indeed need to be helped. So victims of violent crime do not automatically receive compensation.

Compensation is organized by a body called"The Criminal Injuries Compensation Board (CICB)" appointed by the Ministry of Home Affairs. This agency stipulates compensation for "personal injury" resulting directly from: criminal acts, detention of suspects / defendants, criminal precautions, acts of assisting the police in the efforts to make arrests / detention of defendants or suspects, or assisting the police in efforts to prevent crimes. The agency also considers how far the role and contribution of victims to the occurrence of criminal acts.

\section{Counseling}

In general, this protection is given to victims as a result of the emergence of negative impacts that are psychic in nature of a criminal act. Providing assistance in the form of counseling is very suitable given to victims of crimes that leave prolonged trauma, as in cases related to decency.

For example in cases of domestic violence or cases of rape that inflict prolonged trauma on the victim, in general the victim suffers physically, mentally and socially. In addition to suffering physically, the victim also experiences mental distress for example because he feels himself dirty, sinful, and has no future. Even worse, rape victims are often found to be excluded from society because it is considered a disgrace to their families and surrounding communities. By paying attention to the condition of the victim as above, of course a form of assistance or assistance (counseling) that is psychic is relatively more suitable given to the victim than just compensation in the form of money.

\section{Medical Services/Assistance}

Awarded to victims who suffer medically as a result of a criminal offence. The medical services in question can be in the form of medical examinations and written reports (visum or medical certificate that has the same legal force as the evidence). This medical information is necessary especially if the crime that befalls the victim reaches the level of examination in court.

\section{Legal Aid}

It is a form of assistance to victims of crime. The provision of legal assistance to victims of crime must be given either requested or not requested by the victim. This is important to do given the low level of legal awareness of most of the victims who suffer from this violence. The attitude 
of allowing victims of crime not to obtain proper legal assistance can result in worsening conditions of victims of crime.

\section{Provision of information}

Providing information to the victim or his family in connection with the investigation and examination of crimes experienced by the victim. The provision of this information plays a very important role in the efforts to make the community as a partner of the police force, because through this information it is expected that the function of community control to the performance of the police can run effectively.

One of the efforts that has been made by the police in providing information to victims or their families is through the creation of web sites in several police stations in which the police activities are fully presented, both policy and operational. Similarly, notices about the development of criminal investigations and information about the discovery of criminal objects (such as stolen motor vehicles) can be included in this group.

When considered more comprehensively, the impression appears that victims of crime have not obtained adequate protection, influenced by several factors, including: factors of the Law, Victim Legal Awareness, Supporting Facilities and Human Resources. Finally, the legal impartiality of the victim who seems lame when compared to the suspect (defendant), seen from the existence of some laws and regulations that give more "privileges" to the suspect (defendant) than to the victim.
Therefore, it is very important to immediately draft a legislation that specifically regulates the protection of victims of crime, in which will be regulated regarding the protection of victims of crime comprehensively, such as physical, financial, psychic, and medical protection. The most important thing about this law is that protection is not only directed at victims of crimes that capture the public's attention, such as victims of human rights crimes or Terrorism, but all types of crimes. Hopefully good efforts to provide legal protection to victims of crime not only become slogans, but how to implement in a real action.

\section{CONCLUSION}

Legal protection for victims of crime, especially children and women who are victims in the criminal justice system through the process of law enforcement has not obtained the protection that mamadai. Whereas in the concept of state law, it should be a form of legal protection needs to get protection in large portions as a form of state protection to the community. So impressed in the implementation of the victim is often ruled out to obtain adequate justice.

The lack of oversight of protection and justice guarantees led to violent practices, with women and children being the most vulnerable groups experiencing various acts of violence and discrimination. Until now, various forms of discrimination and violence still occur in Indonesia even tend to increase. In fact, the protection of the kroban of crime should be taken seriously by the government. Victims and families should also have the support of the recovery 
process from the state. Perpetrators of sexual violence should be punished fairly according to what they have done. Likewise with law enforcement, still gender bias or blaming the victim.

\section{REFERENCES}

Arief, Barda Nawawi, Perlindungan Korban Kejahatan dalam Proses Peradilan Pidana, Jurnal Hukum Pidana dan Kriminologi, Vol. 1, 1998.

Kebijakan Penegakan Hukum dan Pengembangan Hukum Pidana, Bandung: PT. Citra Aditya Bakti, 1998.
-----------------------, Kapita Selekta Hukum Pidana, Bandung: Citra Aditya Bakti, 2010.

Atmasasmita, Romli., Sistem Peradilan Pidana Kontemporer, Jakarta: Kencana, 2010.

Frank, Jerome, Mr. Justice Holmes and Non-Euclicdian Legal Thingking, Cornel Law Quarterly, 1932.

Hadita, Cynthia., Registrasi Data Pribadi Melalui Kartu Prabayar Dalam Perspektif Hak Asasi Manusia (Provision of Personal Information in Prepaid SIM Card Registration from Human Rights Perspective), Jurnal HAM, Vol. 9, No. 2, December (2018).

Hadita, Cynthia., Regional Autonomy Political Politics Of Regional Liability Reports To Regional Representatives In The Implementation Of Local Government, Nomoi Law Review, Volume 1, Issue 1, May (2020).
Hatta, Moh., Beberapa Masalah Penegakan Hukum Pidana Umum dan Pidana Khusus, Yogyakarta: Liberty Yogyakarta, 2009.

Joutsen, Matti, The Role of The Victim of Crime in European Criminal Justice System, Helsinki: Heuni, 1987.

Kumpulan Pidato-Pidato Pengukuhan, Beberapa Guru Besar Berbicara Tentang Hukum dan Pendidikan Hukum, Bandung: Alumni, 1981.

Mansyur, Dikdik M. Arief., dan Elisatris Gultom, Urgensi Pelrindungan Korban Kejahatan: Antara Norma dan Realita, Jakarta: PT. RajaGrafindo Persada, 2007.

Mujahidin, Ahmad, Peradilan Satu Atap di Indonesia, Bandung: Refika Aditama, 2007.

Nonet, Philippe., dan Philip Selznick, Law and Society in Transition: Toward Responsive Law, New York: Harper \& Row Publisher, 1978.

Pound, Roscoe., Jurisprudence, St. Paul, Minn: West Publishing, 1959.

R. Abdussalam, Prospek Hukum Pidana Indonesia Dalam Mewujudkan Rasa Keadilan Masyarakat, Jakarta: Restu Agung, 2006.

Rahardjo, Satjipto., Penegakan Hukum Suatu Tinjauan Sosiologis, Yogyakarta: Genta Publishing, 2009.

Sanit, Arbi, Perwakilan Politik di Indonesia, Jakarta: Rajawali, 1985.

Sihombing, Eka N.A.M., Pemberlakuan "Parliamentary Threshold" dan Kaitannya dengan Hak Asasi Manusia, Jurnal Konstitusi, Vol. 1, No. 1, Juni (2009).

Sihombing, Eka N.A.M., Mendorong Pembentukan Peraturan Daerah tentang 
Bantuan Hukum di Provinsi Sumatera Utara (Encourage of Establishing Regional Regulation Concerning Legal Aid at Province of North Sumatera), Jurnal Rechtvinding, Vol. 7, No. 3, December (2018).

Soeparman, Parman., Pengaturan Hak

Mengajukan Upaya Hukum Peninjauan Kembali Dalam Perkara Pidana Bagi Korban Kejahatan, Bandung: PT. Refika Aditama, 2007.

Sudarto, Kapita Selekta Hukum Pidana, Alumni, Bandung, 1986.

Theo, Upaya Perlindungan Korban Kejahatan Melalui Lembaga Restitusi dan Kompensasi, Media Hukum dan Keadilan. Vol. II, No. 9, Juni 2003.

Wahid, Abdul., Muhammad Irfan, Perlindungan Terhadap Korban Kekerasan Seksual (Advokasi atas Hak Asasi Perempuan), Bandung: PT. Refika Aditama, 2001.

Weda, Made Darma., Kriminologi, Jakarta: PT. RajaGrafindo Persada, 1996.

Yulia, Rena., Viktimologi (Perlindungan Hukum Terhadap Korban Kejahatan), Yogyakarta: Graha Ilmu, 2010. 